Check for updates

The BMJ

Cite this as: BMJ 2020;371:m4112 http://dx.doi.org/10.1136/bmj.m4112 Published: 23 October 2020

\title{
Covid-19: Government shelves plans to invest f100bn in mass testing
}

\section{Gareth lacobucci}

The UK government has abandoned plans to spend £1oobn on a massive expansion of its national testing programme, legal documents have shown.

A letter from government lawyers also reveals that the ambitious Operation Moonshot programme, first revealed in leaked documents seen by The BMJ last month, has now been quietly subsumed by the national test and trace programme. ${ }^{12}$

The documents seen by The BMJ last month detailed the government's plan to carry out 10 million tests a day by early 2021. They showed that ministers were prepared to spend almost as much as the budget of the NHS in England each year (£13obn) to fund mass testing of the population "to support economic activity and a return to normal life.”

But a letter from government lawyers dated 6 October, issued in response to a threat of legal action against the proposals from the not-for-profit Good Law Project, shows that the government has modified its plans.

The Good Law Project claimed that the Moonshot project was unlawful because it ignored scientific evidence and committed a vast sum of public money with no transparency as to how the decisions were made. ${ }^{3}$ In their response the government's lawyers wrote, "The Project Moonshot Briefing Pack [which was among the documents leaked to The BMJ] was a document designed to provoke discussion: it did not and does not reflect an adopted policy.

"There has been no decision to approve and commit £1oobn of public money to Project Moonshot. Indeed ... no financial commitment has been entered into approaching anything like that sum."

The letter added that the proposal referred to in the Moonshot briefing pack was developed alongside the existing NHS Test and Trace programme, which has an approved “core” budget of approximately £12.1bn.

"The substance of the proposal referred to in the Project Moonshot Briefing Pack has since been subsumed within NHSTT [NHS Test and Trace], reflecting the fast-moving and constantly evolving policy requirements in the field of testing," the letter said. "It has come to be referred to as part of NHSTT's 'mass testing' programme."

In a statement the Good Law Project, which is led by the barrister Jolyon Maugham, said, "The 'Operation Moonshot,' the Government's grand plan to develop a rapid turnaround testing programme, has predictably fizzled out into a damp squib.

“It's a far cry from Boris Johnson's grandstanding in Parliament just a matter of weeks ago and more proof of the mess this Government is making of the UK's testing programme.
"But call it what you like-'Operation Moonshot' or Test and Trace-the Government continues to refuse to answer some really rather basic questions we have been asking for some weeks about their plans for a mass testing programme. Our lawyers have written to the Government yet again to press for transparency."

Specifically, the Good Law project said it was still seeking answers from the government as to why contracts relating to the testing programme were awarded without a competitive tender process, why the National Screening Committee was not consulted over the plans for rapid testing, and whether tests delivered by the programme will be free of charge.

A spokesperson for the Department of Health and Social Care for England said, "We continue to work tirelessly to make sure everyone who needs a test can get one, including by introducing new, highly reliable technology to allow us to test more people and deliver rapid results.

"NHS Test and Trace is the biggest testing system per head of population of all the major countries in Europe. Due diligence is carried out for all government contracts, and we take these checks extremely seriously."

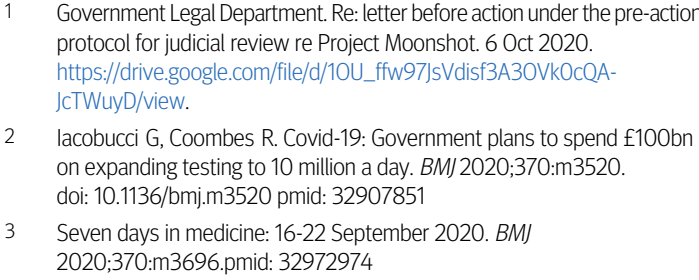

This article is made freely available for use in accordance with BMJ's website terms and conditions for the duration of the covid-19 pandemic or until otherwise determined by BMJ. You may use, download and print the article for any lawful, non-commercial purpose (including text and data mining) provided that all copyright notices and trade marks are retained. 